\title{
Growth Rate and Yield of Two Tomato Varieties (Lycopersicon esculentum Mill) under Green Manure and NPK Fertilizer Rate Samaru Northern Guinea Savanna
}

\author{
A. S. Isah, ${ }^{1}$ E. B. Amans, ${ }^{1}$ E. C. Odion, ${ }^{1}$ and A. A. Yusuf $^{2}$ \\ ${ }^{1}$ Department of Agronomy, Faculty of Agriculture, Ahmadu Bello University, PMB 1044, Zaria, Nigeria \\ ${ }^{2}$ Department of Soil Science, Faculty of Agriculture, Ahmadu Bello University, PMB 1044, Zaria, Nigeria \\ Correspondence should be addressed to A. S. Isah; shero4me@gmail.com
}

Received 29 July 2013; Revised 28 November 2013; Accepted 26 December 2013; Published 20 February 2014

Academic Editor: A. V. Barker

Copyright (C) 2014 A. S. Isah et al. This is an open access article distributed under the Creative Commons Attribution License, which permits unrestricted use, distribution, and reproduction in any medium, provided the original work is properly cited.

Field experiments were conducted in 2010-2011 and 2011-2012 dry seasons at the Research farm of the Institute for Agricultural Research, Samaru northern guinea savanna agro ecological zone of Nigeria to study growth rate and yield of tomato under green manure and NPK fertilizer rates. Treatment consisted of two tomato varieties (Roma VF and UC82B), four rates of NPK 15-1515 fertilizer $\left(0,150,300\right.$, and $\left.450 \mathrm{~kg} \mathrm{ha}^{-1}\right)$, and three rates of green manure $\left(0,5\right.$, and $\left.10 \mathrm{tha}^{-1}\right)$, laid in a split-plot design with three replications. The variety and fertilizer constituted the main plot while green manure was allocated in subplot. Both varieties responded linearly in growth stages of 5 and 7 weeks after transplanting (WAT) on plant height, relative growth rate, and crop growth rate (CGR). However, UC82B proves superior over Roma VF on growth indices CGR at 5-7 WAT, net assimilation rate (NAR) at 7-9 WAT, and total fruit yield with 10.6\% higher. Application of NPK fertilizer significantly increased growth such as plant height, crop dry weight, crop growth rate, and yield. Application between 250 and $280 \mathrm{~kg} \mathrm{ha}^{-1} \mathrm{NPK}$ fertilizers was found efficient for total fruit yield.

\section{Introduction}

Tomato (Lycopersicon esculentum Mill) belongs to the family Solanaceae and is one of the most widely eaten vegetables in the world which popularly stems from the fact that they can be eaten fresh or in multiple of processed forms. In the recent decades, the consumption of tomatoes has been associated with prevention of several diseases $[1,2]$ mainly due to the content of antioxidants including carotenes, (Lycopene as well as $\beta$-carotene), ascorbic acid, and phenolic compounds [3]. The world production of tomato figure in 2012 was 145.8 metric tonnes with China leading with 41.9 metric tonnes. In Africa, Egypt is the leading producer with the production of 39.5 metric tonnes and Nigeria is the fourth in Africa and leads in West Africa subregion with an estimated output of 1.10 metric tonnes and average yield of 10 tonnes ha ${ }^{-1}$ [4].

Increased productivity is attained only when tomato is grown adopting improved varieties and agrotechniques.
Tomato productivity at a given location depends on the potential of the genotype used and timely availability of resources. Low and declining soil fertility is a major concern in many African small holder farms and has been exacerbated by continuous cultivation without adequate soil fertility enhancement measures $[5,6]$. Use of inorganic fertilizers can improve crop yields but its use is limited due to scarcity, high cost, nutrient imbalance, and soil acidity [7]. Green manure has received renewed attention with emphasis on long term sustainability of agricultural system because it can be used as a source of soil nutrients and alternative to maintenance of soil fertility [8], but green manure as a source of soil fertility is not a common practice among vegetable crop production especially tomato in this region. Herbaceous legumes (Lablab purpureus) offer a low cost opportunity for maintaining soil fertility by contributing nutrient during decomposition with slow release of nutrient which may be better timed with plant uptake while reducing nutrients losses $[9,10]$. Adequate 
fertilizer application is required by tomato for growth and yield at the same time sustaining productivity through the use of green manure. Research information is lacking on adequate use of short duration green manure, NPK fertilizer and improved tomato varieties. Therefore this research was design to provide the physiological growth of tomato under green manure and NPK fertilizer rate.

\section{Materials and Methods}

The studies were conducted in 2010-2011 and 2011-2012 dry seasons in the Research Farm of the Institute for Agricultural Research, $\left(11^{\circ} 11^{\prime} \mathrm{N}, 07^{\circ} 38^{\prime} \mathrm{E}, 686 \mathrm{~m}\right.$ above the sea level) Samaru in the Northern Guinea Savanna ecological zone.

The treatments consisted of two tomato varieties (Roma VF and UC82B), four rates of NPK 15-15-15 fertilizer $(0,150$, 300 , and $\left.450 \mathrm{~kg} \mathrm{ha}^{-1}\right)$, and three rates of green manure $(0$, 5 , and $\left.10 \mathrm{tha}^{-1}\right)$. The treatments were laid out in a splitplot design with three replications. A factorial combination of NPK fertilizer and tomato varieties were assigned to the main plot treatment while green manure rates constituted the subplot treatment. The plots are prepared in sunken beds with gross plot size measured $4.0 \mathrm{~m} \times 3.0 \mathrm{~m}\left(12 \mathrm{~m}^{2}\right)$. The soil samples were taken randomly at $30 \mathrm{~cm}$ depth and green manure fodder was analyzed for physicochemical properties and chemical composition of green manure, respectively (Tables 1 and 2).

\section{Green Manure Production}

Two seeds of lablab were sown per hole at spacing of $15 \mathrm{~cm}$ $\times 15 \mathrm{~cm}$ in each side of the ridge in Samaru on 25th October 2010 and 7th November 2011 in the plots where lablab was incorporated. In all years, green manure was incorporated 7 weeks after sowing (i.e., the onset of flowering) according to treatment and allowed to decompose for 3 weeks. The land was harrowed and ridged Lablab purpureus was planted on both side of the ridges at spacing of $15 \mathrm{~cm} \times 15 \mathrm{~cm}$, which was later uprooted, weighted, and incorporated into the soil at 7 weeks after sowing into plots assigned for green manure to its equivalent. The green manure was buried on the furrow for 3 weeks after which the sunken beds were prepared manually measuring $12 \mathrm{~m}^{2}$ and evenly spread in the plot. Transplanting of the seedlings was done 4 weeks after sowing. Roots of vigorous tomato seedlings were dipped into the slurry of phosphate fertilizer (Single super phosphate of $18 \%$ ) thoroughly mixed with soil which was made into slurry and transplanted at spacing of $50 \mathrm{~cm} \times 50 \mathrm{~cm}$ apart and 48 plants were obtained per plot of each variety given an estimated plant population of 40, 000 plants per $\mathrm{ha}^{-1}$.

Compound fertilizer (NPK 15-15-15) was used as source of NPK treatment and was applied at varying rates of 150 , 300 , and $450 \mathrm{~kg} \mathrm{ha}^{-1}$ equivalent to $45: 22.5: 22.5,90: 45: 45$, and $135: 67.867 .8 \mathrm{~kg} \mathrm{ha}^{-1}$ according to treatments. These rates were applied at two weeks after transplanting and urea $46 \%$ was used at six weeks to argument the nitrogen by top dressing. Irrigation was supplied through controlled flooding of the plot (Basin) at 5-7 days interval depending on the stage
TABLE 1: Physical and chemical properties of soils at experimental sites in Samaru during 2010-2011 and 2011-2012 dry seasons.

\begin{tabular}{lcc}
\hline \multirow{2}{*}{ Physical properties (\%) } & \multicolumn{2}{c}{ Year } \\
\hline Sandy & $2010-2011$ & $2011-2012$ \\
Silt & 40.0 & 44.0 \\
Clay & 30.3 & 31.0 \\
Textural class & 28.7 & 25.0 \\
Chemical properties & Loam & Loam \\
pH in water & & \\
pH $\left(0.0 \mathrm{CaCl}_{2}\right)$ & 5.6 & 6.2 \\
Organic carbon $\left(\mathrm{g} \mathrm{kg}^{-1}\right)$ & 4.9 & 5.3 \\
$\quad$ Available phosphorus $\left(\mathrm{mg} \mathrm{kg}^{-1}\right)$ & 0.72 & 0.72 \\
$\quad$ Total nitrogen $\left(\mathrm{g} \mathrm{kg}^{-1}\right)$ & 14.3 & 14.3 \\
Exchangeable bases $\left(\mathrm{cmol} \mathrm{kg}^{-1}\right)$ & 0.42 & 0.52 \\
$\mathrm{Ca}^{++}$ & & \\
$\mathrm{Mg}^{++}$ & 1.80 & 1.80 \\
$\mathrm{~K}^{+}$ & 0.32 & 1.20 \\
$\mathrm{Na}^{++}$ & 0.17 & 0.33 \\
Exchangeable acidity $_{\mathrm{CEC}}$ & 0.25 & 0.05 \\
\end{tabular}

Source: analyzed soil samples at Soil science Department's laboratory, A.B.U., Zaria.

TABLE 2: Chemical composition of Lablab green manure used at Samaru in 2010-2011 and 2011-2012.

\begin{tabular}{lcc}
\hline Chemical composition & $2010-2011$ & $2011-2012$ \\
\hline Total nitrogen $\left(\mathrm{g} \mathrm{kg}^{-1}\right)$ & 36.6 & 35.7 \\
Total phosphorus $\left(\mathrm{g} \mathrm{kg}^{-1}\right)$ & 5.5 & 6.1 \\
Potassium $\left(\mathrm{g} \mathrm{kg}^{-1}\right)$ & 10.8 & 12.0 \\
Calcium $\left(\mathrm{g} \mathrm{kg}^{-1}\right)$ & 10.3 & 10.6 \\
Carbon $(\%)$ & 48.8 & 49.7 \\
$\mathrm{C}: \mathrm{N}$ ratio & 13 & 14 \\
Dry matter $\left(\mathrm{g} \mathrm{kg}^{-1}\right)$ & 456.5 & 460.5 \\
\hline
\end{tabular}

Source: analyzed green manure sample at Soil science Department's laboratory, A.B.U., Zaria.

of crop. Manual hoe weeding was also employed to control weeds at 4 and 8 weeks after transplanting.

Plant height was determined with the use of tape rule measured from the base of the plant above the ground to the last expanded leaf of growing tip and expressed in centimeters. Also the crop dry weight was determined by weighing the vegetative part which was cut at the base of the plant above ground level and were taken periodically and subsequently at 2 weeks intervals of 5, 7, and 9 WAT. The above crops at each sampling period were oven-dried to a constant weight and weighed in grams [11]. From the dry matter, crop growth rate and relative growth rate were computed.

Crop growth rate is the rate of dry matter production per plant per unit time. It was calculated by using the following formulae and expressed as $\mathrm{g} \mathrm{wk}^{-1}$ plant $^{-1}$ at 5-7 and 79 WAT.

CGR $=W_{2}-W_{1} / t_{2}-t_{1} \mathrm{~g} \mathrm{wk}^{-1}$ plant $^{-1}$, where $W_{1}=$ Dry weight of the plant at time $t_{1}$ and $W_{2}=$ Dry weight of the plant at time $t_{2}$ 
TABLE 3: Influence of NPK fertilizer and green manure rates on plant height and crop growth rate per plant of two tomato varieties in Samaru, 2010-2011 and 2011-2012 dry season.

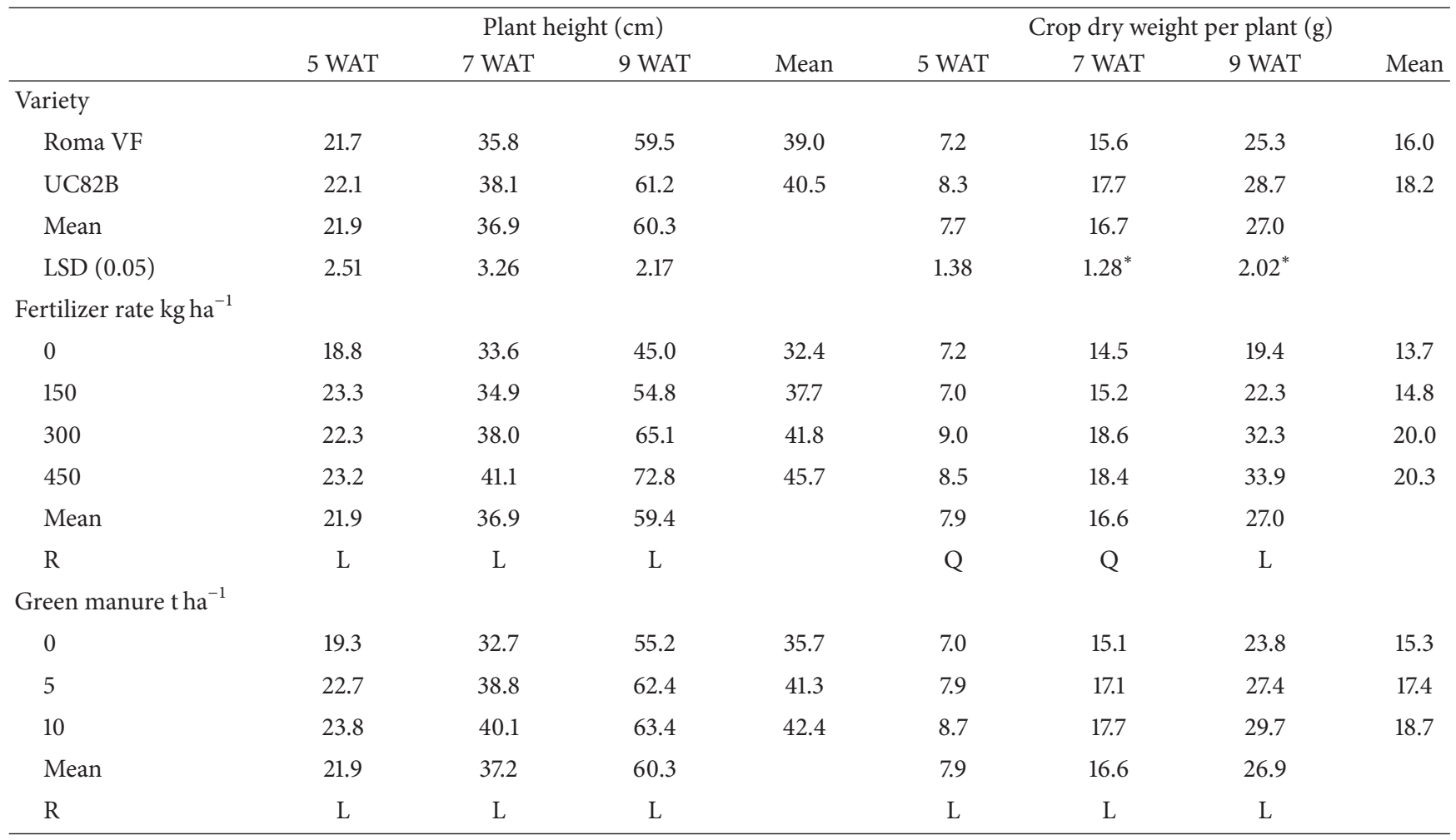

${ }^{*}$ Significant at $P \leq 0.05$, R: regression, L: linear, and Q: quadratic response.

Relative growth rate at various stages was calculated as suggested by Radford [12] at 5-7 and 7-9 WAT. RGR $=\ln W_{2}-$ $\ln W_{1} / t_{2}-t_{1} \mathrm{~g} \mathrm{~g}^{-1} \mathrm{wk}^{-1}$, where $\ln =$ Natural log, $W_{1}=$ Dry weight of plant (g) at time $t_{1}$ and $W_{2}=$ Dry weight of plant (g) at time $t_{2}$.

Total fruit yield $\left(\mathrm{tha}^{-1}\right)$ : The cumulative total fruit harvested obtained spanning 6-7 weeks including the nonmarketable ones were weighed per plot and their yield was expressed in tonnes per ha ${ }^{-1}$.

\section{Data Analysis}

All the data collected from the observations for two years were averaged and subjected to analysis of variance (ANOVA) using general linear model GLM as described by Steel and Torrie [13], varieties were compared using least significant differences (LSDs) and regression analyses were used to assess the trends in fertilizer and green manure application, and graphs were plotted.

\section{Results}

The soil physicochemical properties are given in (Table 1) which showed that the soil of the study area is loam and slightly acidic ranging from 5.6 to 6.2 with low organic carbon. The total $\mathrm{N}\left(0.42-0.52 \mathrm{~g} \mathrm{~kg}^{-1}\right)$ was low and exchangeable bases were generally low. However, the soil had high available phosphorus. The chemical composition of green manure used for the study was presented in (Table 2). The material had high total $\mathrm{N}$ content value between 35.7 and $36.6 \mathrm{~g} \mathrm{~kg}^{-1}$ with a high tendency of rapid fodder degradation as indicated by the $\mathrm{C}: \mathrm{N}$ ratio between 13 and 14 . Therefore, it is a good source of organic material that will supply nutrients and soil quality.

\section{Plant Height and Crop Dry Weight}

The response of variety to plant height per plant was not significant throughout the sampling periods $(P>0.05)$ which is presented in (Table 3, Figure 1). Similarly at 5 weeks after transplanting, crop dry weight was not significant while 7 and 9 WAT varietal response was significant on crop dry weight where UC82B produced more dry weight than Roma VF (Table 3, Figure 1).

Application of fertilizer increases plant height and crop dry weight (Table 3 ). The trend showed a linear response in all the sampling periods on plant height while in the crop dry weight regression analyses showed quadratic response at all sampling (Figure 1(a)). The crop dry weight at 9 WAT coefficient of determination $\left(R^{2}=0.922\right)$ was the highest as compared to 7 WAT $\left(R^{2}=0.845\right)$ and 5 WAT $\left(R^{2}=0.604\right)$; the optimum fertilizer rate was therefore projected as $300 \mathrm{~kg}$ NPK ha ${ }^{-1}$. 


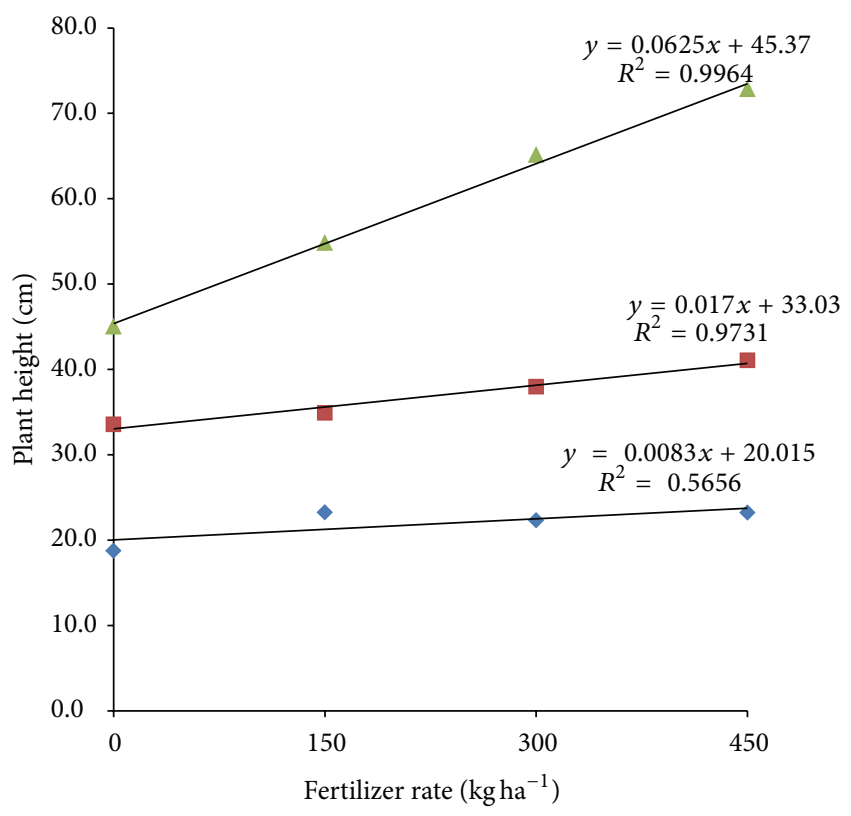

(a)

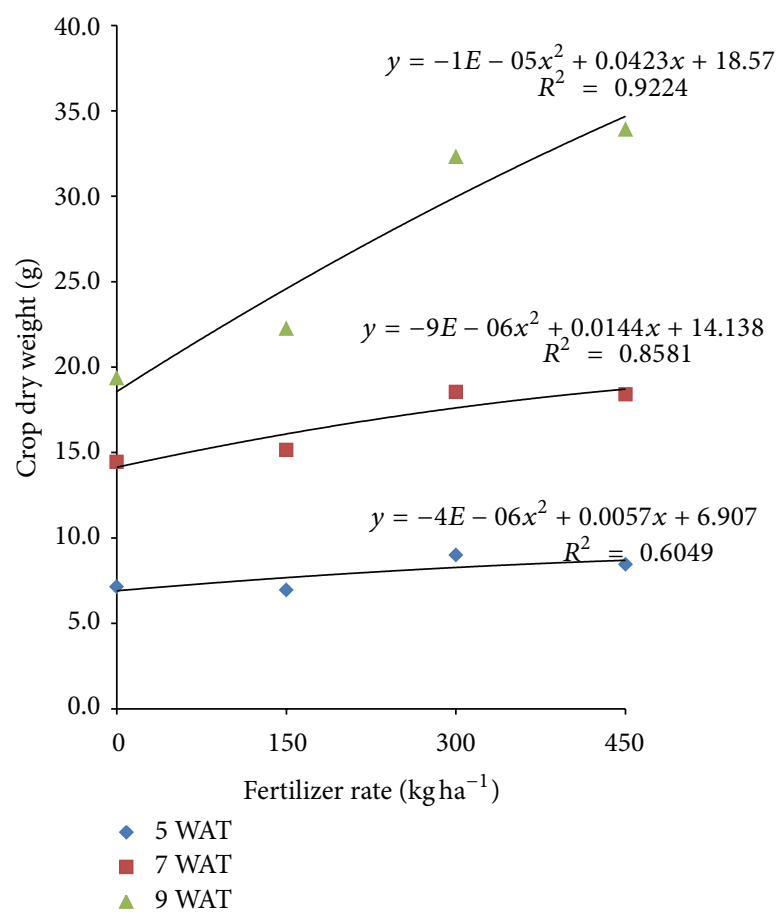

(c)

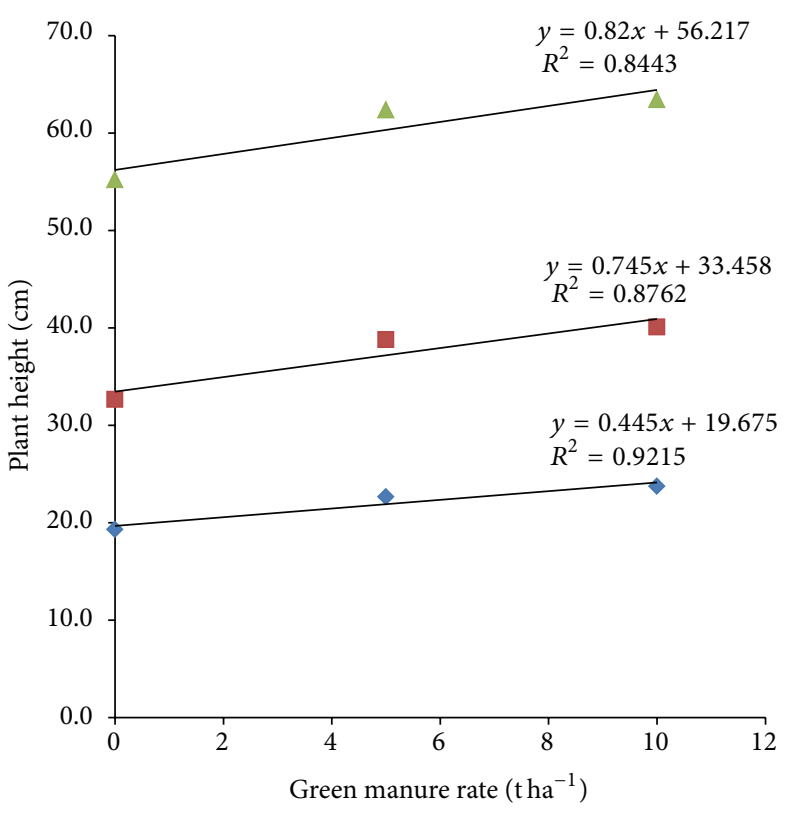

(b)

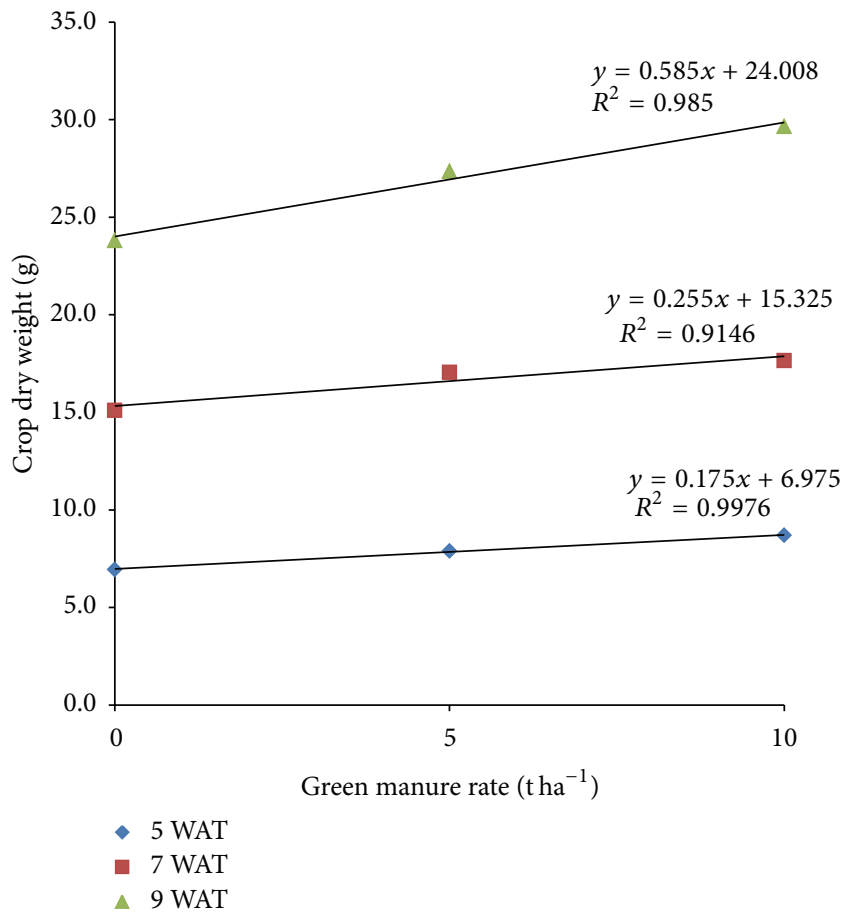

(d)

FIGURE 1: Effect of NPK fertilizer and green manure rate on plant height (a) and (b), crop dry weight (c) and (d) of tomato.

Similarly, green manure application increases plant height and crop dry weight is presented in Figures 1(b) and 1(c). The trends showed that applied green manure was linear, plant height followed the regression at 5, 7, and 9 WAT with determination of $R^{2}=0.921,0.876$, and 0.844 , respectively. Also crop dry weights at 5 WAT $\left(R^{2}=0.997\right), 7$ WAT $\left(R^{2}=\right.$ $0.914)$, and 9 WAT $\left(R^{2}=0.985\right)$ were linear.

\section{Relative Growth Rate and Crop Growth Rate}

The varietal responsess on relative growth rate (RGR) and crop growth rate were not significant $P>0.05$ which is presented in (Table 4). RGR and CGR showed a linear response to fertilizer rate and green manure application (Figures 2(a) and 2(c)). When fertilizer was used for RGR 


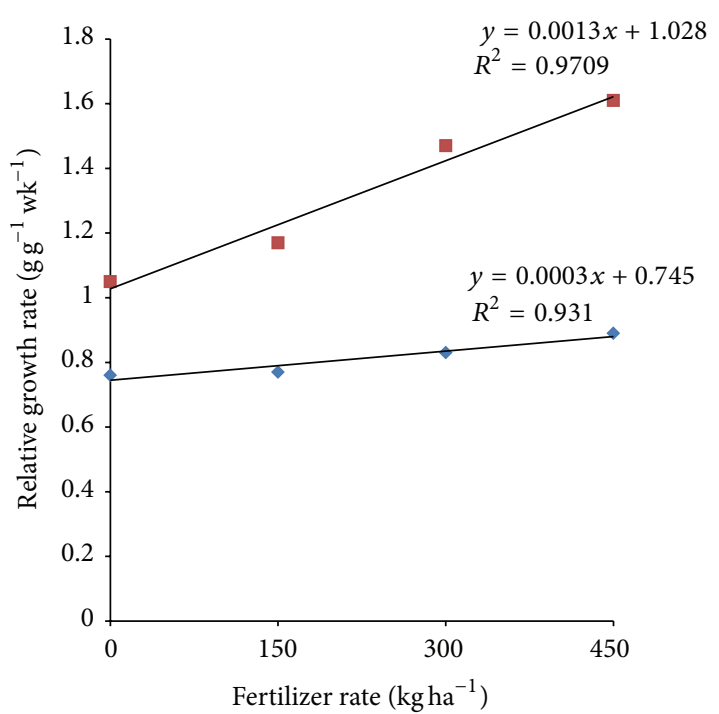

(a)

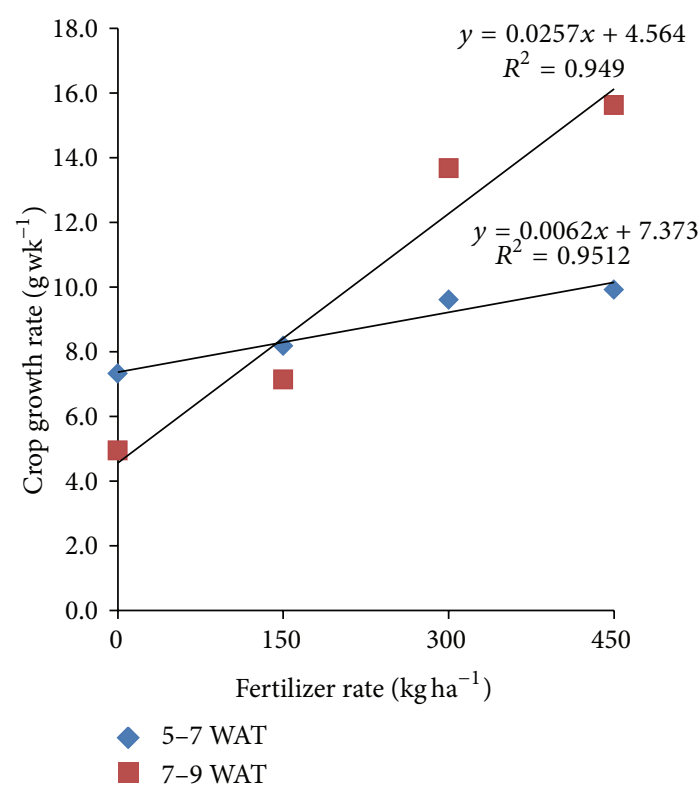

(c)

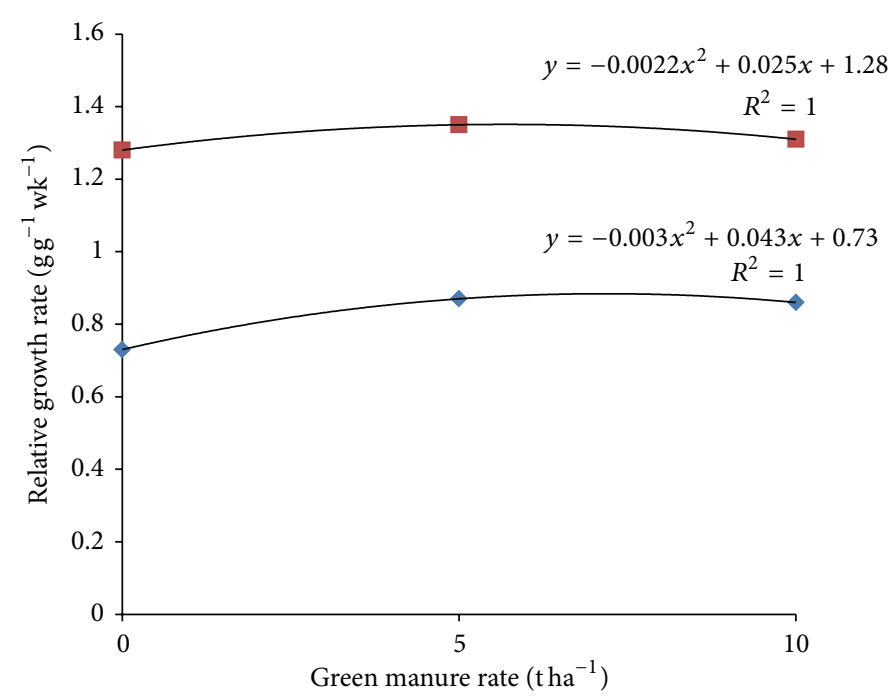

(b)

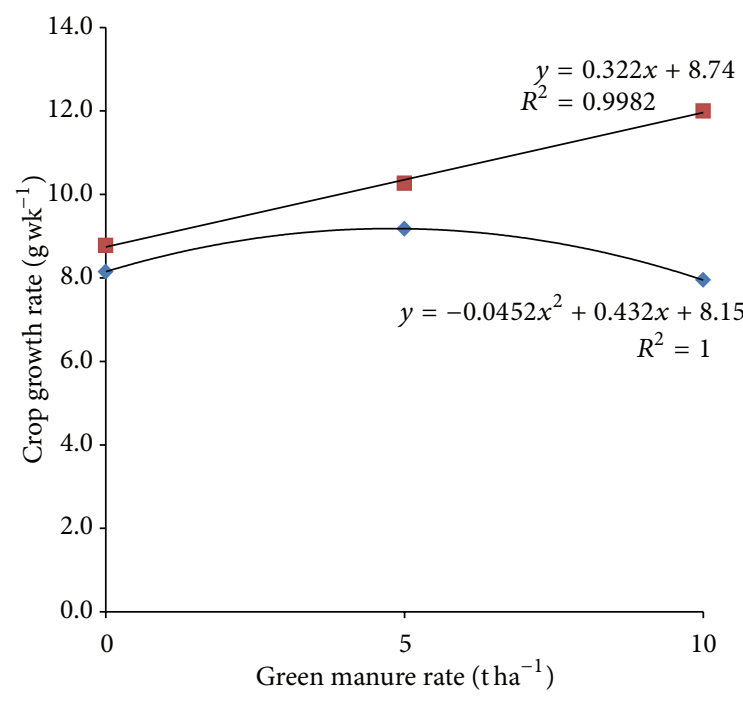

(d)

FigURE 2: Effect of NPK fertilizer and green manure rate on the relative growth rate (a) and (b) and crop growth rate (c) and (d) of tomato.

(Figure 2(a)), the response followed the regression equations at 5-7 WAT $y=0.000 x+0.745\left(R^{2}=0.931\right)$ and 7-9 WAT $y=0.001 x+1.028\left(R^{2}=0.970\right)$ while CGR at 5-7 WAT $y=$ $0.025 x+4.564\left(R^{2}=0.949\right)$ and 7-9 WAT $y=0.006 x+7.373$ $\left(R^{2}=0.951\right)$, respectively.

Regression analysis showed that the optimum RGR of 0.87 and $1.35 \mathrm{gg} \mathrm{wk}^{-1}$ was obtained with green manure rates of 6.25 and $7.17 \mathrm{t} / \mathrm{ha}$ at 5-7 and 7-9 WAT in (Figure 2(b)), respectively. The optimum green manure rate for CGR at 57 WAT was therefore projected as $4.8 \mathrm{tha}^{-1}$ with $9.2 \mathrm{~g} \mathrm{wk}^{-1}$ being obtained while at 7-9 WAT CGR showed a linear response (Figure 2(d)).

\section{Total Fruit Yield $\mathrm{tha}^{-1}$}

Variety showed that a significant difference to total fruit yield per ha ${ }^{-1}$ is presented in (Table 4). UC82B significantly produce more total fruit yield $\mathrm{ha}^{-1}$ than Roma VF where it had $10.6 \%$ higher on the average. Fruit yield showed a quadratic response to fertilizer rate (Figure 3(a)). When fertilizer was used regression, analysis showed that the optimum fruit yield of 16.8 and $18.6 \mathrm{tha}^{-1}$ was obtained with application of fertilizer rates of 250 and $280 \mathrm{~kg} \mathrm{NPK} \mathrm{ha}^{-1}$ for Roma VF and UC82B, respectively. When green manure was used (Figure 3(b)), the fruit yield for both varieties showed a linear 


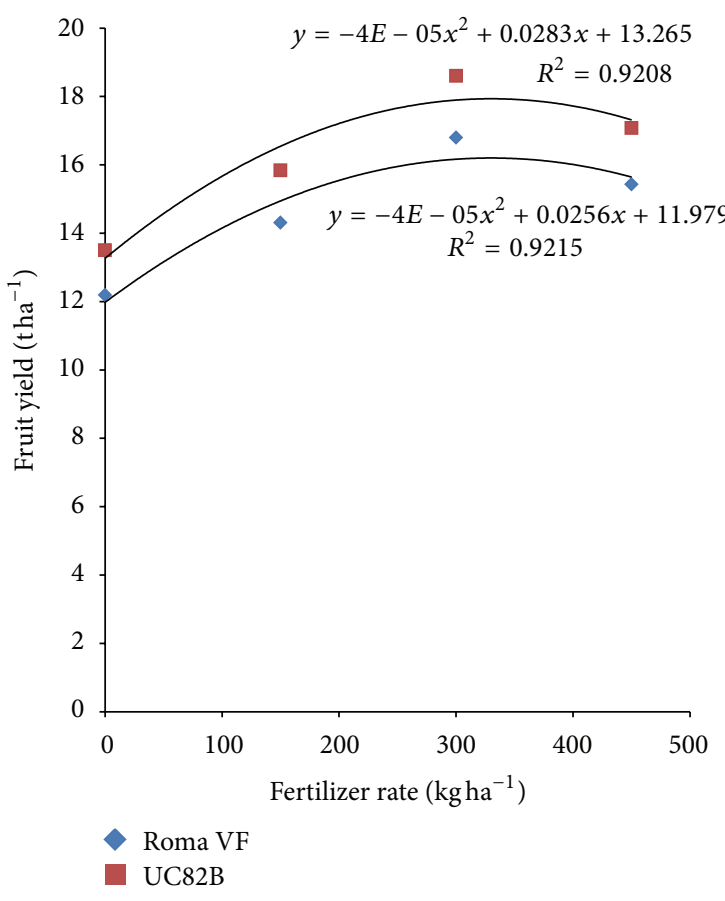

(a)

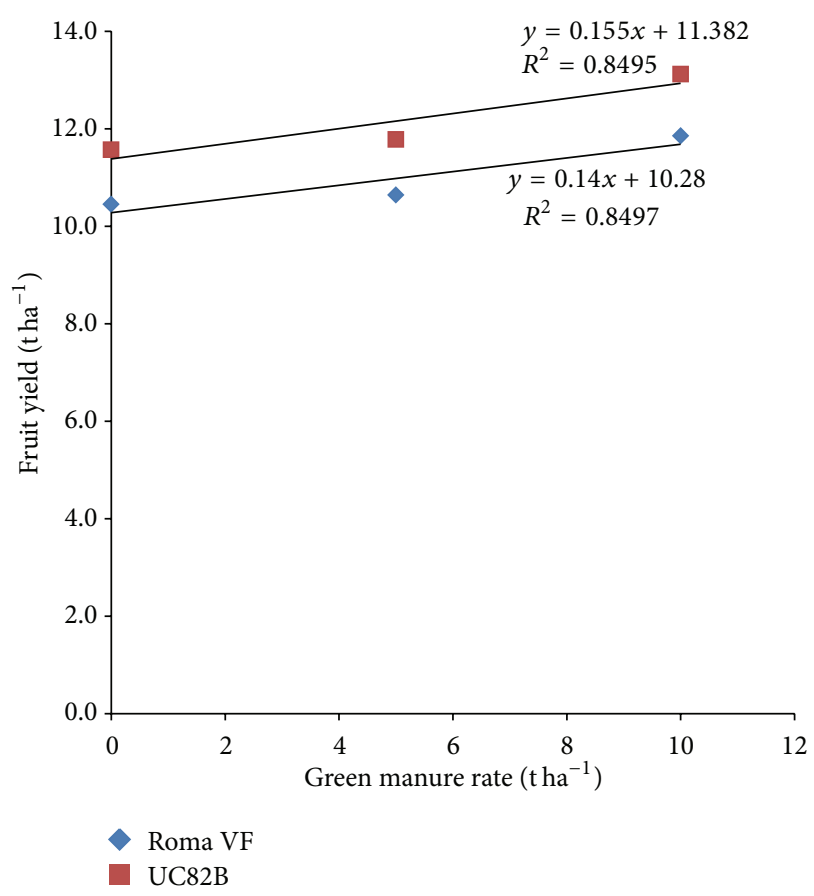

(b)

FIGURE 3: Regression analysis based on mean value of NPK fertilizer rate (a) and green manure rate (b) of two tomato varieties fruit yield $\mathrm{tha}^{-1}$.

response, Roma VF $y=0.186 x+13.71\left(R^{2}=0.848\right)$ and $\mathrm{UC} 82 \mathrm{~B} y=0.206 x+15.17\left(R^{2}=0.848\right)$.

\section{Discussion}

The soil analysis showed clearly that the nutrient status of the soil is low except phosphorus which was high. Therefore, crop response to fertilizer application is expected under such soil conditions [14]. The poor fertility status may be connected to nature and continuous cultivation of the soil over the years, that may influenced the soil texture. The green material used for the study was rich in supplying major nutrients with rapid tendency of decomposition.

The overall performance of tomato plant as exemplified by crop dry weight and crop growth rate, was good determinant to yield throughout the study period. Varieties differ in their growth and yield potential depending mainly on the physiological process which is controlled by interplay of both genetic make-up and the environment. Differential performance of this variety could be attributed to genetic variability adaptability, morphological features, and physiological factors during the crop growth period. The reports by Olaniyi et al. [15] indicated that UC82B was higher in the growth attributes of tomato than other varieties evaluated.

In this study, application of NPK fertilizer enhances growth of two tomato varieties. Tomato growth increases as expressed by the increases observed in plant height, crop dry weight, crop growth rate, and relative growth rate. The higher response of tomato to the growth might be due to the availability of essential elements from inorganic fertilizer. This observation is in agreement with that of Nafiu et al. [16]. The result of this study demonstrated that highest yields of tomato were obtained from the plots treated with NPK fertilizer compared to the control.

In this study, tomato responded to green manuring in plots that received green manure rates which produce a better growth as indicated on plant height and crop dry weight. The growth response of tomato to green manure plots relative to control plot in this trial could be attributed to increased organic matter, nitrogen, and possibly other nutrients released from the incorporated green manure. This could be due to overwhelming effect of green manure on total dry matter. Liu et al. [17] and Tonfack et al. [18] reported similar findings. The significant increases in yield components after green manure incorporation are in conformity with those reported by many researchers [19-21].

\section{Conclusion}

Tomato variety UC82B yielded more than Roma VF and the study confirms the valuable contribution of NPK fertilizer and green manure to the growth and yield of tomato. The lablab green manure is readily available and cheaper to plough into soil and $250-280 \mathrm{~kg} \mathrm{ha}^{-1}$ NPK of $15: 15: 15$ should be maintained in this agroecological zone. 
TABLE 4: Influence of NPK fertilizer and green manure rates on Relative growth rate, crop growth rate per plant, and yield of two tomato varieties in Samaru, 2010-2011 and 2011-2012 dry season.

\begin{tabular}{|c|c|c|c|c|c|c|c|}
\hline & \multicolumn{3}{|c|}{ Relative growth rate (RGR) $\mathrm{gg}^{-1} \mathrm{wk}^{-1}$} & \multicolumn{3}{|c|}{ Crop growth rate (CGR) g. $\mathrm{wk}^{-1}$} & \multirow{2}{*}{ Total yield t ha ${ }^{-1}$} \\
\hline & 5-7 WAT & 7-9 WAT & Mean & 5-7 WAT & 7-9 WAT & Mean & \\
\hline \multicolumn{8}{|l|}{ Variety } \\
\hline Roma VF & 0.80 & 1.28 & 1.04 & 8.2 & 9.5 & 8.8 & 11.2 \\
\hline UC82B & 0.84 & 1.36 & 1.10 & 9.4 & 11.0 & 10.2 & 12.4 \\
\hline Mean & 0.82 & 1.32 & & 8.8 & 10.2 & & 11.8 \\
\hline $\operatorname{LSD}(0.05)$ & 0.120 & 0.143 & & 0.86 & 1.51 & & $0.71^{*}$ \\
\hline \multicolumn{8}{|c|}{ Fertilizer rate $\mathrm{kg} \mathrm{ha}^{-1}$} \\
\hline 0 & 0.76 & 1.05 & 0.91 & 7.3 & 5.0 & 6.1 & 9.8 \\
\hline 150 & 0.77 & 1.17 & 0.97 & 8.2 & 7.1 & 7.7 & 11.5 \\
\hline 300 & 0.83 & 1.47 & 1.15 & 9.6 & 13.7 & 11.6 & 13.5 \\
\hline 450 & 0.89 & 1.61 & 1.25 & 9.9 & 15.6 & 12.8 & 12.4 \\
\hline Mean & 0.81 & 1.33 & & 8.8 & 10.3 & & 11.8 \\
\hline $\mathrm{R}$ & $\mathrm{L}$ & $\mathrm{L}$ & & $\mathrm{L}$ & $\mathrm{L}$ & & $\mathrm{Q}$ \\
\hline \multicolumn{8}{|c|}{ Green Manure tha ${ }^{-1}$} \\
\hline 0 & 0.73 & 1.28 & 1.01 & 8.2 & 8.8 & 8.5 & 11.2 \\
\hline 5 & 0.87 & 1.35 & 1.11 & 9.2 & 10.3 & 9.7 & 11.4 \\
\hline 10 & 0.86 & 1.31 & 1.09 & 8.0 & 12.0 & 10.0 & 12.7 \\
\hline Mean & 0.82 & 1.31 & & 8.4 & 10.4 & & 11.8 \\
\hline $\mathrm{R}$ & Q & Q & & Q & $\mathrm{L}$ & & $\mathrm{L}$ \\
\hline
\end{tabular}

${ }^{*}$ Significant at $P \leq 0.05$, R: regression, L: linear, and Q: quadratic response.

\section{Conflict of Interests}

The authors declare that there is no conflict of interests regarding the publication of this paper.

\section{References}

[1] J. K. Willcox, G. L. Catignani, and S. Lazarus, "Tomatoes and cardiovascular health," Critical Reviews in Food Science and Nutrition, vol. 43, no. 1, pp. 1-18, 2003.

[2] Y. Sharoni and Y. Levi, "Cancer prevention by dietary tomato lycopene and its molecular mechanisms," in Tomatoes, Lycopene \& Human Health, A. V. Rao, Ed., pp. 111-125, Caledonian Science Press Ltd, Barcelona, Spain, 2006.

[3] M. J. Periago, J. García-Alonso, K. Jacob et al., "Bioactive compounds, folates and antioxidant properties of tomatoes (Lycopersicum esculentum) during vine ripening," International Journal of Food Sciences and Nutrition, vol. 60, no. 8, pp. 694-708, 2009.

[4] FAO, "Faostat," 2012, http://faostat.fao.org/site/339/default.aspx.

[5] S. M. Nandwa, "Soil organic carbon (SOC) management for sustainable productivity of cropping and agro-forestry systems in Eastern and Southern Africa," Nutrient Cycling in Agroecosystems, vol. 61, no. 1-2, pp. 143-158, 2001.

[6] S. K. Kimani, S. M. Nandwa, D. N. Mugendi et al., "Principles of soil fertility management," in Soil Fertility Management in Africa: A Regional Perspective, M. P. Gichuru, A. Bationo, M. A. Bekunda et al., Eds., Academy Science Publishers, 2003.

[7] D. E. Okwu and N. S. Ukanwa, "Nutritive value and phytochemical contents of flute pumpkin (Telfaria occidentalis Hook) vegetable grown with different levels of turkey droppings," in Proceedings of the 8th African Crop Science Society Conference, vol. 8, pp. 1759-1964, 2007.
[8] M. Ali, "Evaluation of green manure technology in tropical lowland rice systems," Field Crops Research, vol. 61, no. 1, pp. 61-78, 1999.

[9] B. Bath, Matching the availability of $N$ mineralised from crops with the N-demand of field vegetables [Doctoral thesis unpublished], Swedish University of Agricultural Science, Uppsala, Sweden, 2000.

[10] B. Ibewiro, N. Sanginga, B. Vanlauwe, and R. Merckx, "Nitrogen contributions from decomposing cover crop residues to maize in a tropical derived savanna," Nutrient Cycling in Agroecosystems, vol. 57, no. 2, pp. 131-140, 2000.

[11] R. Hunt, Plant Growth Analysis, vol. 96 of Studies in Biology, Edward Arnold, London, UK, 1982.

[12] P. J. Radford, "Growth analysis formulae, their uses and abuse," Crop Science, vol. 3, pp. 171-173, 1967.

[13] R. G. D. Steel and J. H. Torrie, Principles and Procedures of Statistics. A Biometrical Approach, McGraw-Hill, New York, NY, USA, 1987.

[14] M. A. N. Anikwe, C. I. Okonkwo, and N. L. Aniekwe, "The effect of changing land use on selected soil properties in the Abakaliki agroecological zone, south-eastern Nigeria," International Journal of Environmental Education and Information, vol. 18, no. 1, pp. 79-84, 1999.

[15] J. O. Olaniyi, W. B. Akanbi, T. A. Adejumo, and O. G. Akande, "Growth, fruit yield and nutritional quality of tomato varieties," African Journal of Food Science, vol. 4, no. 6, pp. 398-3402, 2010.

[16] A. K. Nafiu, A. O. Togun, M. O. Abiodun, and V. O. Chude, "Effects of NPK fertilizer on growth, drymatter production and yield of eggplant in southwestern Nigeria," Agriculture and Biology Journal of North America, vol. 2, no. 7, pp. 1117-1125, 2011.

[17] B. Liu, M. L. Gumpertz, S. Hu, and J. B. Ristaino, "Long-term effects of organic and synthetic soil fertility amendments on soil microbial communities and the development of southern 
blight," Soil Biology and Biochemistry, vol. 39, no. 9, pp. 23022316, 2007.

[18] L. B. Tonfack, A. Bernadac, E. Youmbi, V. P. Mbouapouognigni, M. Ngueguim, and A. Akoa, "Impact of organic and inorganic fertilizers on tomato vigor, yield and fruit composition under tropical andosol soil conditions," Fruits, vol. 64, no. 3, pp. 167177, 2009.

[19] A. O. Togun, W. B. Akanbi, and J. A. Adediran, "Growth, nutrient uptake and yield of tomato in response to different plant residue compost," Food Agriculture and Environment, vol. 2, no. 1, pp. 310-316, 2004.

[20] D. I. Akanni and S. O. Ojeniyi, "Effect of different levels of poultry manure on soil physical properties, nutrients status growth and yield of tomato (Lycopersicum escunlentus)," Journal of Agronomy, vol. 1, pp. 1-4, 2007.

[21] M. Rashidi and F. Keshavarzpour, "Effect of different tillage methods on soil physical properties and crop yield of watermelon (Citrullus vulgaris)," ARPN Journal of Agricultural and Biological Science, vol. 2, no. 6, pp. 1-16, 2007. 


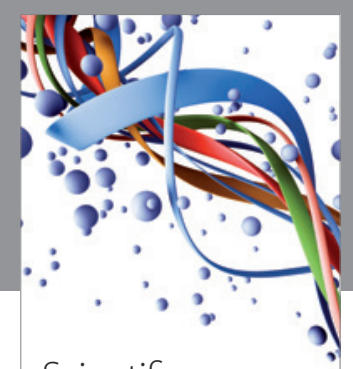

Scientifica
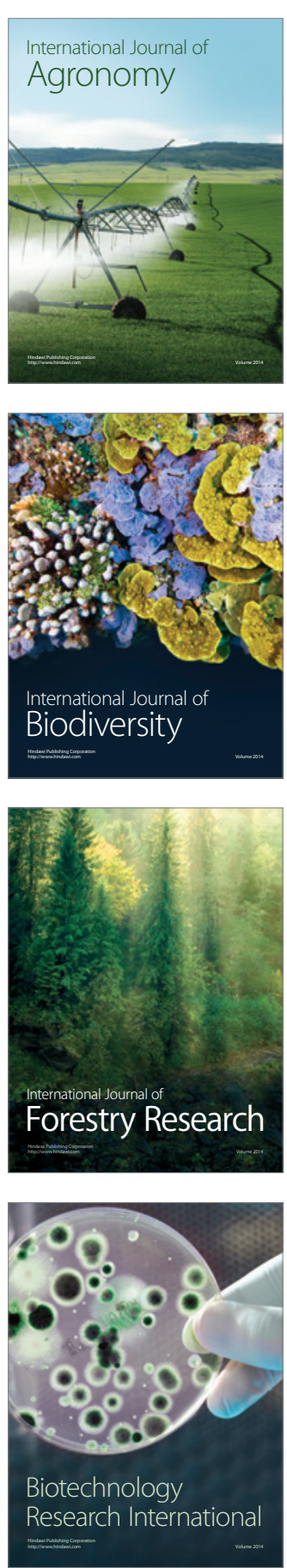
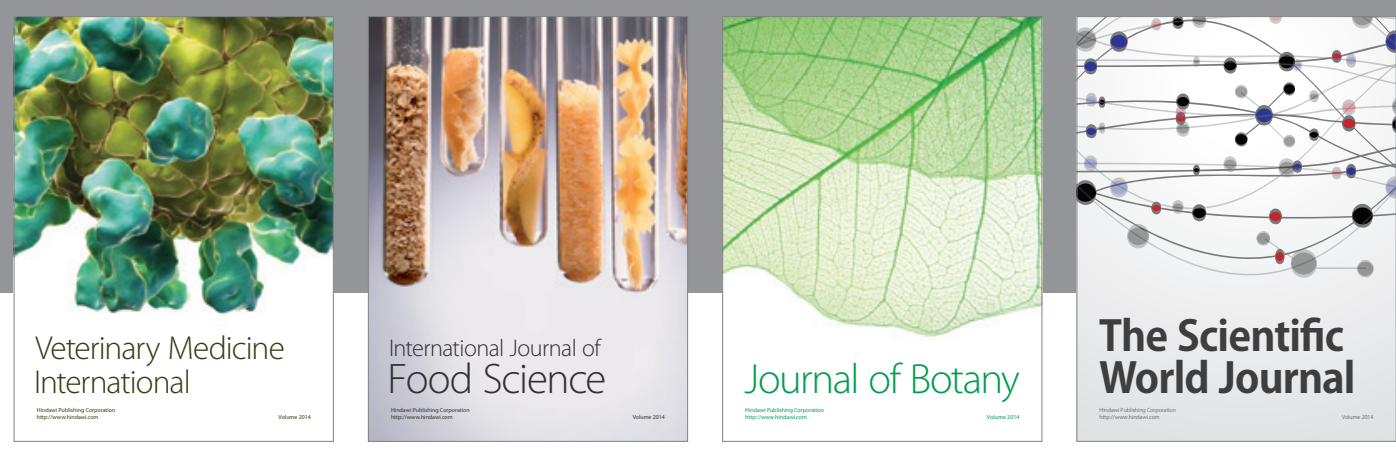

The Scientific World Journal
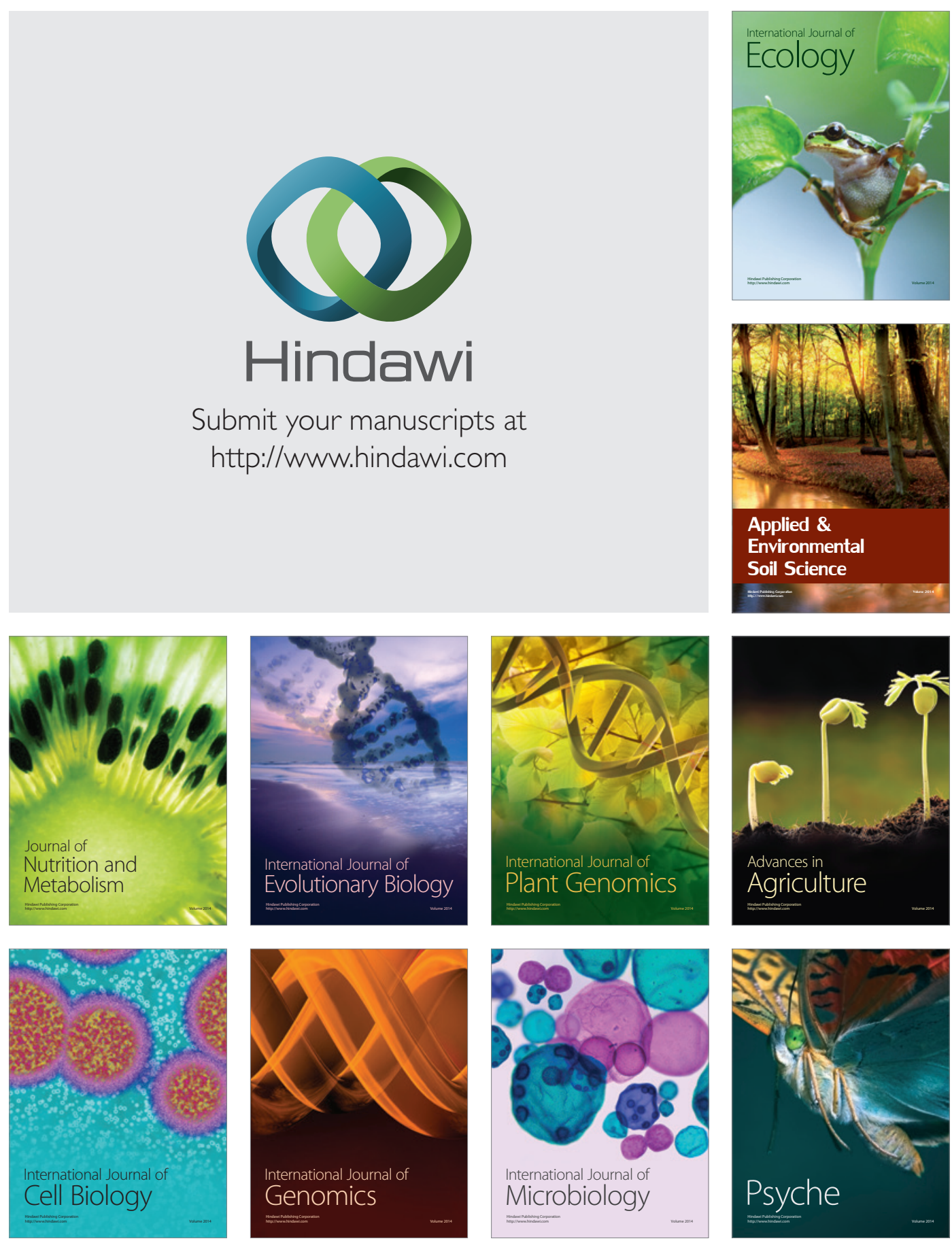